\title{
REFERENCES
}

Beilinsohn, A. (1929). J. Biol. Méd. exp. Moscou, 11, 52. Cited from Chem. Abstr. 1930, 24, 1427.

Boursnell, J. C., Dangerfield, W. G. \& Wormall, A. (1939). Biochem. J. 33, 81 .

Boursnell, J. C. \& Wormall, A. (1939). Biochem. J. 33, 1191.

Cole, S. W. (1933). Practical Physiological Chemistry, 9th ed. Cambridge: W. Heffer and Sons.

Dangerfield, W. G., Gaunt, W. E. \& Wormall, A. (1938). Biochem. J. 32, 59.
Fürth, O., Scholl, R. \& Herrmann, H. (1932). Wien. klin. Wschr. 45, 1012.

Handbook of Chemistry and Physics (1936). 21st ed. Cleveland, Ohio: Chem. Rubber Publishing Co.

Klopstock, F. (1932). Z. ImmunForsch. 75, 348.

Mayer, M. \& Zeiss, H. (1921). Arch. Schiffs.- u. Tropenhyg. 25, 259.

Quastel, J. H. (1931). Biochem. J. 25, 1121.

\section{Chemistry of Tissues}

\section{POLYSACCHARIDES SHOWING BLOOD GROUP A-SPECIFICITY AND THE NATURE OF THE CONSTITUENT UNITS OF THE STABLE CARBOHYDRATE RESIDUE OF THE A SUBSTANCE FROM PEPSIN}

\author{
By H. G. BRAY, H. HENRY AND M. STACEY, From the Departments of Physiology \\ and Chemistry, University of Birmingham
}

\section{(Received 15 September 1945)}

The chemistry of the blood group substances presents problems of lively interest in both the protein and carbohydrate fields and it is apparent that precise structural knowledge of these substances is eminently desirable in order to understand the remarkable differences in specificity which exist between the various groups. Two types of material, differing in immunological behaviour but sharing a common group specificity, are available for examination. One type, which probably contains lipid constituents in addition to carbohydrate, can be extracted by organic solvents from human tissues and erythrocytes, while the other type can be extracted by water from certain human and animal tissues and secretions. Adequate recent reviews on the subject have been presented by Wiener (1943) and Morgan (1944). One of the most striking observations in considering the field as a whole is the absence of any reliable method for preparing the 'group substances proper' from erythrocytes themselves and the consequent failure to establish more than a serological connexion between these group substances proper and the related substances in tissues. Nevertheless, the determination of the chemical nature of the tissue substances does present a relatively easy approach to the problem. The main part of the work described herein was completed some 6 years ago and was largely designed to find a suitable source of the factors and to work out a method for giving the relatively large amounts of carbohydrate material necessary for study by the methylation and other techniques. The purification was controlled by determining the power of each fraction to inhibit the isoagglutination reaction only, for no opportunity was found to carry out the haemolytic inhibition test (cf. Morgan, 1944). The properties of the substances examined are set forth in the experimental section and are summarized in Table 1. Their significance is discussed later. Table 2 shows typical specimens of blood group A factors described in the literature.

\section{EXPERIMENTAL}

The following modification of the method of Sevag (1934) was found suitable for the preparation of a soluble polysaccharide-amino-acid complex from a wide variety of sources.

The mucin or minced tissue suspension was heated at $100^{\circ}$ for periods up to $30 \mathrm{~min}$. in a steamer and where necessary a little $\mathrm{CaCO}_{3}$ was added to maintain neutrality. The solution was cooled and filtered. To each $100 \mathrm{ml}$. of filtrate there was added sodium acetate (12-16 g.) and $20 \%(\mathrm{w} / \mathrm{v})$ acetic acid $(10-12 \mathrm{ml}$.) to adjust the solution to $\mathrm{pH} 4 \cdot 8$. It was then vigorously shaken with chloroform (or carbon tetrachloride) $(20 \mathrm{ml}$.) and with butanol $(2 \mathrm{ml}$.) for $30 \mathrm{~min}$. The mixture was centrifuged and the upper layer separated and again shaken with Sevag's reagents several times until there was no further coagulation of extraneous protein material. The crude polysaccharide was precipitated from the solution by addition of 3-4 vol. of ethanol. It was then fractionated by precipitation from $5 \%$ aqueous solution containing a few drops of $1 \%$ calcium chloride, by gradual addition of ethanol. The fractions were dried by being washed with absolute ethanol and ether and then kept in a vacuum at $20^{\circ}$. 


\section{Technique of titration of polysaccharides}

The degree of activity of the polysaccharides dealt with in this paper has been estimated by determining their neutralizing capacity against the corresponding agglutinins present in appropriate normal human serum. The same anti-A ( $\alpha$ ) serum, which was obtained from the Galton Laboratory, Oxford, was used for titrating the whole series of group A substances. Group A red cells were obtained from the same individual throughout. The red cells were well washed with large volumes of physiological saline and then made up in such a concentration as to give easily discernible reactions when mixed with progressive dilutions of anti-serum. Equal volumes of cell-suspension and of anti-serum were mixed together on a clean microscope slide which was kept in a moist chamber at room temperature for $1 \mathrm{hr}$., the final reaction being read by means of a Busch $2 \times 28$ binocular microscope.
It was thus possible to measure the number of agglutinin units in each $\mathrm{ml}$. of a given anti-A $(\alpha)$ serum. Since anti-sera keep unimpaired for long periods in cold storage, and since freshly prepared red cell suspensions can be standardized by means of a haemoglobinometer, it is possible to carry out a series of agglutination determinations under similar conditions and so to obtain results that are reasonably comparable.

The titration of the polysaccharide fractions was carried out as follows: $5 \mathrm{mg}$. of each was taken up in $5 \mathrm{ml}$. of sterile physiological saline to give a concentration of 1 in 1000 . From this solution there were made dilutions of 1 in 5000, 1 in 50,000, 1 in 500,000 and 1 in 5,000,000. Five drops of each dilution were set out on a glazed porcelain spot-plate and to each there was added an equal volume of anti-A $(\alpha)$ serum in a 1 in 5 dilution; the mixtures were then kept at room temperature for $1 \mathrm{hr}$. One drop of each mixture was then added to one drop of cell suspension on a clean microscope slide which was kept in a moist chamber for $1 \mathrm{hr}$. After this time the dilution point at which the agglutination reaction was not inhibited, was recorded.

Table 1. Properties of carbohydrate material obtained from various sources

\begin{tabular}{|c|c|c|c|c|c|c|c|}
\hline \multirow[b]{2}{*}{ Sample } & \multirow[b]{2}{*}{ Source } & \multirow{2}{*}{$\begin{array}{c}{[\alpha]_{D}^{20^{\circ}} \text { in }} \\
\text { water }\end{array}$} & \multirow{2}{*}{$\underset{(\%)}{N}$} & \multirow{2}{*}{$\begin{array}{c}\text { Minimum } \\
\text { amount } \\
\text { detectable } \\
\text { by anti-A }(\alpha) \\
\text { isoagglutina- } \\
\text { tion test }\end{array}$} & $\begin{array}{c}\text { Biuret } \\
\text { test }\end{array}$ & $\underbrace{\begin{array}{c}\text { Sakaguchi } \\
\text { test }\end{array}}$ & $\begin{array}{l}\text { Diazo- } \\
\text { sulphanilic } \\
\text { acid test }\end{array}$ \\
\hline & & & & & \multicolumn{3}{|c|}{ Tested in $2 \%$ aqueous solution } \\
\hline $\begin{array}{l}S(1) \\
S(2)\end{array}$ & $\begin{array}{l}\text { Human saliva group A } \\
\text { Human saliva group B }\end{array}$ & $\begin{array}{l}+10^{\circ} \\
+20^{\circ}\end{array}$ & $\begin{array}{l}4 \cdot 8 \\
4 \cdot 5\end{array}$ & $\begin{array}{l}4 \mu \mathrm{g} \text {. } \\
\text { No action (but } \\
4 \mu \mathrm{g} . \text { against } \\
\text { anti-B serum) }\end{array}$ & $\begin{array}{l}+ \\
+\end{array}$ & $\begin{array}{l}+ \\
+\end{array}$ & $\begin{array}{l}+ \\
+\end{array}$ \\
\hline S (3) & Hog mucin & $+10^{\circ}$ & $3 \cdot 5$ & $4 \mu \mathrm{g}$ & + & + & + \\
\hline $\mathrm{S}(4)$ & Pepsin & $-20^{\circ}$ & $5 \cdot 2$ & $2 \mu \mathrm{g}$ & + & ++ & + \\
\hline S (5) & 'Neopeptone'* & $+5^{\circ}$ & $5 \cdot 5$ & $4 \mu \mathrm{g}$ & + & + & + \\
\hline $\mathrm{S}(6)$ & 'Peptone'* & $+6^{\circ}$ & $5 \cdot 0$ & $4 \mu \mathrm{g}$ & + & + & + \\
\hline $\mathrm{S}(7)$ & Beef pancreas & $-15^{\circ}$ & $6 \cdot 8$ & $4 \mu \mathrm{g}$ & + & + & + \\
\hline $\mathrm{S}(8)$ & Commercial pancreatin* & $-25^{\circ}$ & $6 \cdot 5$ & $4 \mu \mathrm{g}$ & + & + & + \\
\hline $\mathrm{S}(9)$ & Lower intestinal mucin & $-6^{\circ}$ & $5 \cdot 0$ & Inactive & + & + & + \\
\hline $\mathrm{S}(10)$ & Sheep pituitary & $-30^{\circ}$ & $6 \cdot 5$ & Inactive & + & + & - \\
\hline S (11) & Human cartilage & $-33^{\circ}$ & $3 \cdot 2$ & Inactive & - & - & - \\
\hline $\mathrm{S}(12)$ & Beef cartilage & $-31^{\circ}$ & $2 \cdot 8$ & Inactive & - & - & - \\
\hline $\mathrm{S}(13)$ & Serum mucoid & $-35^{\circ}$ & $11 \cdot 5$ & Inactive & + & + & + \\
\hline S (14) & Ovomucoid & $-35^{\circ}$ & $11 \cdot 4$ & $1000 \mu \mathrm{g}$ & + & + & + \\
\hline S (15) & Frog spawn mucin & - & $6 \cdot 8$ & $10 \mu \mathrm{g}$ & + & + & + \\
\hline$S(16)$ & Pig vitreous humour & - & 6.5 & Inactive & + & - & - \\
\hline $\mathrm{S}(17)$ & Gum tragacanth & - & Trace & Inactive & - & - & - \\
\hline S (18) & Damson gum & - & Trace & $120 \mu \mathrm{g}$ & - & - & - \\
\hline S (19) & Pepsin & $+12^{\circ}$ & $3 \cdot 8$ & $0 \cdot 1 \mu \mathrm{g}$ & + & ++ & + \\
\hline$S(20)$ & Pepsin & $+6^{\circ}$ & $3 \cdot 9$ & $1 \mu \mathrm{g}$ & + & + & + \\
\hline S (21) & Pepsin & $-3^{\circ}$ & $3 \cdot 5$ & $2 \mu \mathrm{g}$ & + & + & + \\
\hline $\mathrm{S}(22)$ & Pepsin & $-10^{\circ}$ & $2 \cdot 6$ & $10 \mu \mathrm{g}$ & + & \pm & + \\
\hline $\mathrm{S}(23)$ & Frog spawn, carbohydrate residue & $+6^{\circ}$ & $5 \cdot 8$ & Inactive & \pm & $\overline{-}$ & - \\
\hline $\mathrm{S}(24)$ & Ovomucoid, carbohydrate residue & $-30^{\circ}$ & $5 \cdot 4$ & Inactive & - & - & - \\
\hline $\mathrm{S}(25)$ & Hog mucin (copper purification) & $+5^{\circ}$ & $4 \cdot 8$ & $10 \mu \mathrm{g}$ & + & + & + \\
\hline S (26) & Hog mucin, acetylated & $+6^{\circ}$ & $2 \cdot 5$ & $100 \mu \mathrm{g}$ & \pm & \pm & \pm \\
\hline $\mathrm{S}(27)$ & Hog mucin, deacetylated material & $+15^{\circ}$ & $4 \cdot 5$ & $10 \mu \mathrm{g}$ & + & \pm & + \\
\hline $\mathrm{S}(28)$ & Human erythrocytes & $+2^{\circ}$ & $2 \cdot 8$ & Trace & - & - & - \\
\hline $\mathrm{S}(29)$ & Human erythrocytes & $+5^{\circ}$ & $2 \cdot 5$ & Trace & - & - & - \\
\hline
\end{tabular}

*. British Drug House Ltd. 
This preliminary titration with dilutions by powers of 10 gives a clear indication of the limiting zone in which neutralization of agglutination occurs, and the exact point of neutralization can be reached by interpolation of a fresh series of dilutions by powers of 2 .

Since the dilution of polysaccharide which neutralizes a known dilution of antiserum is determined when equal volumes of both are used, it follows that the neutralizing capacity of a sample of polysaccharide can be expressed as that amount which inhibits one agglutination unit. A similar technique was used in testing for group B substances, using an appropriate anti-B $(\beta)$ serum and group $B$ cells from one individual.

Polysaccharide preparations. With 'active' preparations, only the properties of those fractions showing the most marked reaction are recorded in Table 1. In some cases the fractions were tested for their anti-B $(\beta)$ power also. No claim can be made that any of the substances was homogeneous, but it was readily apparent that commercial pepsin and commercial hog mucin form convenient sources of material for further purification and chemical investigation. Samples were made from the tissues or mucins listed in Table 1.

\section{Further examination of the pepsin A substance}

Inasmuch as the most active material $\mathrm{S}(4)$ from pepsin still retained a laevo rotation $[\alpha]_{D}^{18^{\circ}},-20^{\circ}$ (cf. Table 2) and gave a strong biuret test, attempts were by $\mathrm{Dr}$ W. T. J. Morgan having isoagglutinin power in a dilution of $0.15 \mu \mathrm{g} . / \mathrm{ml}$. (cf. Morgan \& King, 1943).

Hydrolysis of the pepsin $A$ substance with $0.1 \mathrm{~N}-$ $\mathrm{NaOH}$. A $5 \%$ solution of S (19) was heated at $100^{\circ}$ with $0 \cdot 1 \mathrm{~N}-\mathrm{NaOH}$ and measured samples taken at intervals. After the heating process the withdrawn sample was cooled, neutralized with acetic acid, taken down to small bulk in a vacuum and the product precipitated by 4 vol. of ethanol, the precipitate being washed and dried as usual. Samples were obtained as follows: $\mathrm{S}(20)$ (30 min. heating), $\mathrm{S}(21)$ (2 hr. heating), $\mathrm{S}(22)$ (4 hr. heating). The effect of the hydrolysis is shown in Table 1.

Similar attempts to remove the amino-acid constituents, using alkaline hydrolysis, were made with the complexes from ovomucoid $S$ (14) and from frog spawn mucin $S(15)$ and there resulted the inactive substances $\mathrm{S}(23)$ and $\mathrm{S}(24)$ (Table 1 ).

\section{Examination of hog mucin A substance}

Inasmuch as $\mathrm{S}(3)$ contained an appreciable amount of nucleic acids (of mixed ribo- and deoxyribo-types) a $2 \%$ solution of this sample was treated with a $5 \%$ solution of copper acetate until no further precipitation occurred. The precipitate (which contained $\mathrm{Cu}$ nucleate along with other impurities) was removed (centrifuge) and the gastric

Table 2. Properties of carbohydrate materials obtained from animal sources by other workers

\begin{tabular}{|c|c|c|c|c|c|c|c|}
\hline Source & $\begin{array}{c}\mathrm{C} \\
(\%)\end{array}$ & $\underset{(\%)}{H}$ & $\stackrel{N}{N}$ & $\begin{array}{c}\text { Reducing } \\
\text { sugar (as } \\
\text { glucose) } \\
(\%)\end{array}$ & $\begin{array}{l}\text { Amino } \\
\text { sugar } \\
(\%)\end{array}$ & $\begin{array}{l}\text { Acetyl } \\
(\%)\end{array}$ & {$[\alpha]$} \\
\hline $\begin{array}{l}\text { Hog pepsin (i) } \\
\text { Horse saliva (ii) } \\
\text { Peptone (iii) }\end{array}$ & $\begin{array}{l}46 \cdot 9 \\
44 \cdot 6 \\
46 \cdot 7 \\
44 \cdot 9\end{array}$ & $\begin{array}{l}6 \cdot 6 \\
6 \cdot 9 \\
6 \cdot 53 \\
6 \cdot 23\end{array}$ & $\begin{array}{l}6 \cdot 2 \\
7 \cdot 1 \\
5 \cdot 85 \\
5 \cdot 48\end{array}$ & $\begin{array}{l}70 \cdot 7 \\
56 \cdot 8 \\
73 \\
62\end{array}$ & $\begin{array}{l}27 \\
=\end{array}$ & $\begin{array}{l}10 \\
9 \cdot 4 \\
9 \cdot 56 \\
8 \cdot 9\end{array}$ & $\begin{array}{l}+16^{\circ} \\
+10^{\circ} \\
+11 \cdot 5^{\circ} \\
+9 \cdot 6^{\circ}\end{array}$ \\
\hline $\begin{array}{l}\text { Hog stomach (iv) } \\
\text { Hog gastric mucin (v) }\end{array}$ & $\begin{array}{c}46-47 \\
44 \cdot 8-45 \cdot 9\end{array}$ & $\begin{array}{l}6 \cdot 6-6 \cdot 9 \\
6 \cdot 4-6 \cdot 6\end{array}$ & $\begin{array}{l}5 \cdot 5-6 \cdot 3 \\
5 \cdot 7-6 \cdot 4\end{array}$ & $\begin{array}{l}50-60 \\
43-50\end{array}$ & $\begin{array}{l}29-30 \\
24-27 \cdot 3\end{array}$ & $\begin{array}{r}10 \cdot 5-12 \cdot 0 \\
9 \cdot 2-11 \cdot 5\end{array}$ & $\begin{array}{l}+19 \cdot 8 \rightarrow+21 \cdot 9^{\circ} \\
+8 \rightarrow+14^{\circ *}\end{array}$ \\
\hline
\end{tabular}

(i) Landsteiner \& Chase (1936).

(ii) Landsteiner (1936).

(iii) Goebel (1938).

(iv) Landsteiner \& Harte (1940).

(v) Morgan \& King (1943).

* $\lambda 5461 \mathrm{~A}$.

made to remove from it as much of the protein material as possible by means of mild alkaline hydrolysis. A $5 \%$ solution of $\mathrm{S}(4)$ was mixed thoroughly with $\mathrm{BaCO}_{3}$ and heated to $70^{\circ}$ for $10 \mathrm{~min}$. The $\mathrm{BaCO}_{3}$ was removed (centrifuge) and by careful fractional precipitation of the material in solution by means of ethanol there was obtained in $60 \%$ yield a group A substance $\left(\mathrm{S}(19):[\alpha]_{D}^{20^{\circ}},+12^{\circ} ; N\right.$. acetyl, $9.4 \%$ ) which had essentially the properties of specific material as described in the literature (Table 2). It showed an isoagglutinin power at a dilution of $0 \cdot 10 \mu \mathrm{g} . / \mathrm{ml}$., which compared favourably with an undegraded electrophoretically homogeneous preparation of an A substance kindly provided mucin polysaccharide precipitated from the supernatant by addition of 4 vol. of ethanol. It was reprecipitated several times from aqueous solution by addition of a mixture of ethanol and ether acidified with $\mathrm{HCl}$ until all the copper ions were removed. It was washed and dried as usual, giving $\mathrm{S}(25)$.

Acetylation of $\mathrm{S}(25)$. $\mathrm{S}(25)(2.0 \mathrm{~g}$.) was suspended in pyridine $(20 \mathrm{ml}$.) and acetic anhydride $(30 \mathrm{ml}$.$) and the$ mixture shaken vigorously at room temperature for $48 \mathrm{hr}$. The resulting clear solution was poured into ice-water which was then thoroughly extracted with chloroform. On removal of the chloroform there was obtained $3 \cdot 2 \mathrm{~g}$. of a cream-coloured powder, $\mathrm{S}(26)$, having $O$-acetyl, $33 \cdot 3 ; N$ - 
acetyl, $9 \cdot 3 ; \mathrm{N}, 1.3 \% ;[\alpha]_{D}^{18^{\circ}},-12^{\circ}$ in chloroform $(c, 1 \cdot 0)$; $[\alpha]_{D}^{20^{\circ}},+6^{\circ}$ in water $(c, 1 \cdot 5)$ (Table 1$)$.

Deacetylation of $\mathrm{S}(26)$. This material (1.5 g.) was dissolved in acetone $(25 \mathrm{ml}$.) and to the solution was added $5 \mathrm{~N}-\mathrm{NaOH}(10 \mathrm{ml}$ ). After being kept for $30 \mathrm{~min}$. a further amount of acetone $(15 \mathrm{ml}$.) was added, the solution centrifuged and the product purified by reprecipitation from a concentrated aqueous solution by means of ethanol acidified with acetic acid. After being dried in the usual manner there was obtained $0.8 \mathrm{~g}$. of $\mathrm{S}(27)$ in the form of a white powder $\left([\alpha]_{D}^{20^{\circ}},+15^{\circ}\right.$ in water $(c, 1 \cdot 1) ; N$-acetyl, $\left.9.0 \%\right)$ (Table 1).

\section{Attempted preparation of the group $A$ substance from human erythrocytes}

The experimental procedures of Hallauer (1934), Kosjakov \& Tribulev (1940), and Kosjakov (1941), and many variations thereof were carefully followed using washed erythrocytes of group A. In most cases it was possible to isolate in very low yield samples of polysaccharide material, e.g. S (28) and $\mathrm{S}(29)$, but in all cases these carbohydrates were devoid of detectable amino-acid constituents and possessed only traces of group A specificity (cf. Morgan, 1944).

\section{Preparation of a stable carbohydrate residue from pepsin A substance for methylation studies}

Since there remained a stable carbohydrate residue, $S(22)$, after alkaline hydrolysis of the most active material S (19), it was felt advisable to carry out a saponification process using barium hydroxide before submitting the polysaccharide to the strongly alkaline conditions of the dimethyl sulphate methylation. Accordingly the following methods were developed:

Method I. This was the modification of the method of Fraenkel \& Jellinck (1927) which Stacey \& Woolley (1940) used for preparing ovomucoid from egg albumin. Material corresponding to $\mathrm{S}(19)$ was prepared as described below. Commercial pepsin (80 g.) and baryta (100 g.) were dissolved in hot water (1 l.), ethanol (50 ml.) and amyl alcohol $(5 \mathrm{ml}$.) were added and the mixture boiled in an atmosphere of nitrogen for $12 \mathrm{hr}$. The residue was separated (centrifuge), washed with water until free from carbohydrate and discarded. The supernatant liquid and washings were concentrated under reduced pressure and the syrup formed poured into ethanol ( $6 \mathrm{vol}$.). The coherent mass which was precipitated was separated (centrifuge) and purified by reprecipitation with ethanol. It was finally obtained as a light brown powder; $[\alpha]_{D}^{20^{\circ}},-9^{\circ}$; yield $15 \%$ of crude pepsin.

Method II. S(19) from commercial pepsin (10 g.) was dissolved in water $\left(100 \mathrm{ml}\right.$.), $\mathrm{BaCO}_{3}(20 \mathrm{~g}$.) added and the mixture heated on a boiling water-bath for $3 \mathrm{hr}$., the volume being maintained by the addition of water when necessary. Baryta (5 g.) was then added and the heating continued for a further $3 \mathrm{hr}$. It was then filtered and the filtrate evaporated in the presence of $\mathrm{BaCO}_{3}(20 \mathrm{~g}$.). After removal of barium salts (centrifuge) the product which remained was precipitated and purified as in method I and was obtained as a pale yellow powder; $[\alpha]_{D}^{20^{\circ}},-10^{\circ}$; yield $20 \%$ of the pepsin used. This product still gave weak biuret and ninhydrin tests.

Acetylation. A mixture of stable carbohydrate residue $(10 \mathrm{~g}$.$) , acetic anhydride (80 \mathrm{ml}$.) and pyridine $(50 \mathrm{ml}$.) was shaken at room temperature for $9 \mathrm{hr}$. The solid material was isolated (centrifuge) and re-treated with acetic anhydride and pyridine. After six treatments no solid material remained. The combined supernatant liquids were evaporated (under diminished pressure) to a dark brown syrup which was dissolved in chloroform and centrifuged. A small insoluble residue was discarded and the supernatant liquid poured into light petroleum (b.p. $40-60^{\circ}$ ). The acetylated carbohydrate material was precipitated as a dark brown powder, which could not be separated into fractions having different properties by means of fractionation with organic solvents, $O$-acetyl, $33 \cdot 0 ; N$-acetyl, $9 \cdot 0 \% ;[\alpha]_{D}^{18^{\circ}},-12^{\circ}$ in chloroform.

Methylation. Both the acetylated and unacetylated materials were methylated and yielded products which, as far as it has been possible to determine by fractionation with organic solvents, were essentially identical.

Direct methylation of the carbohydrate residue. A mixture of stable carbohydrate residue ( $20 \mathrm{~g}$.), water (160 ml.), carbon tetrachloride $(240 \mathrm{ml}$.) and dimethyl sulphate $(80 \mathrm{ml}$.) in a bolthead flask was stirred in a water-bath at $45^{\circ}$, and $35 \% \mathrm{NaOH}$ (160 ml.) added at intervals over $1 \mathrm{hr}$. Dimethyl sulphate $(80 \mathrm{ml}$.$) and 35 \% \mathrm{NaOH}(160 \mathrm{ml}$.) were then added simultaneously during $2 \mathrm{hr}$., the temperature raised to $60^{\circ}$ and the mixture stirred for $2 \mathrm{hr}$. The reaction mixture was cooled to $0^{\circ}$ and neutralized with $5 \mathrm{~N}-\mathrm{H}_{2} \mathrm{SO}_{4}$. $\mathrm{Na}_{2} \mathrm{SO}_{4} .7 \mathrm{H}_{2} \mathrm{O}$ was crystallized out, filtered off, further amounts being precipitated by the addition of ethanol. The filtrate was concentrated (under diminished pressure) to a syrup which was dissolved in water $(150 \mathrm{ml}$.) with acetone $\left(25 \mathrm{ml}\right.$.) and remethylated at $40^{\circ}$ by making quarter-hourly additions of dimethyl sulphate $(13 \mathrm{ml}$.) and $35 \% \mathrm{NaOH}$ (24 ml.), 10 additions in all being made. The temperature was raised to $65^{\circ}$ for $2 \mathrm{hr}$. and the mixture cooled, neutralized and crystalline sodium sulphate removed as before. The filtrate was evaporated to a syrup, dissolved in water $(160 \mathrm{ml}$.) and the above two treatments repeated. The removal of sodium sulphate was then made as complete as possible. The product was a brown, porous, semi-solid mass: ash, $22 \%$; OMe, $25 \%$; yield, $5 \mathrm{~g}$.

This partially methylated material was dissolved in a mixture of dry methanol $(160 \mathrm{ml}$.) and acetic anhydride (12 ml.) and left for $24 \mathrm{hr}$. at ordinary temperature in order to acetylate any free amino groups. The solvents were then removed under diminished pressure at $40-50^{\circ}$. The resulting syrup was dissolved in methyl iodide containing just sufficient dry methanol to give complete solution, silver oxide was added and the mixture maintained at $45^{\circ}$ for 4-5 hr. This treatment was repeated until no further increase in the methoxyl content could be achieved, the maximum value being $31.8 \%$; ash, $2.1 \%$; yield, $3.5 \mathrm{~g}$. The yield could be increased by careful prolonged extraction of the various insoluble residues.

Fractionation of the methylated polysaccharide. A typical sample of the methylated material (4.0 g.; $\mathrm{OMe}, 30.8 \%)$, was dissolved in chloroform ( $10 \%$ solution) and separated into fractions by cautious addition of light petroleum (b.p. $40-60^{\circ}$ ). The 
fractions had properties as follows and provided evidence that the methylated material was homogeneous:

$\begin{array}{cccccc}\begin{array}{c}\text { Frac- } \\ \text { tion }\end{array} & \begin{array}{c}\text { Yield } \\ (\mathrm{g} .)\end{array} & \begin{array}{c}{[\alpha]_{D}^{21^{\circ}} \text { in }} \\ \text { chloroform }\end{array} & \begin{array}{c}\text { OMe } \\ (\%)\end{array} & \begin{array}{c}\text { Ash } \\ (\%)\end{array} & \begin{array}{c}\mathrm{N} \\ (\text { Dumas) } \\ (\%)\end{array} \\ 1 & 0 \cdot 8 & -21 \cdot 4 & 30 \cdot 3 & 1 \cdot 1 & 1.8 \\ 2 & 0.9 & -21.5 & 30.8 & 1 \cdot 1 & 1.9 \\ 3 & 1.2 & -21 \cdot 0 & 30.5 & 1.2 & 1.9 \\ 4 & 1.0 & -20 \cdot 8 & 30.0 & 1.8 & 1.6\end{array}$

This methylated material slowly dialyzed through parchment and collodion membranes, showing that it was of relatively low molecular weight. It probably represents a portion only of the carbohydrate material in the blood group A factor, though it may be a repeating unit.

Hydrolysis. The methylated carbohydrate (3 g.) was hydrolyzed by being refluxed on a boiling water-bath for $20 \mathrm{hr}$. with dry methanol containing $2 \%$ dry hydrogen chloride. In a typical experiment $[\alpha]_{D}^{20},-18 \cdot 5^{\circ}$ changed to $[\alpha]_{D}^{20^{\circ}},+73^{\circ}$ in $24 \mathrm{hr}$. The acid was neutralized with $\mathrm{PbCO}_{3}$ and the filtered liquid evaporated in a vacuum to give a mobile dark brown syrup.

Fractionation. The methylated syrup was separated into three fractions: (a) soluble in ether; $(b)$ insoluble in ether; (c) soluble in a methanol-ether mixture. Fraction $(a)$ was obtained first by a continuous extraction of the hydrolysate with dry ether. The residual insoluble portion was then dissolved in dry methanol (35 ml.) and dry ether added until no further material (fraction $(b)$ ) was precipitated. Evaporation of the methanol-ether gave fraction (c).

Identification of an l-fucose constituent. Vacuum distillation of fraction $(a)$ at $10 \mathrm{~mm} . \mathrm{Hg}$ (water pump) at $100^{\circ}$ gave a crystalline sublimate which was recrystallized from ether and light petroleum. It then had m.p. $89-92^{\circ},[\alpha]_{D}^{19^{\circ}},-187^{\circ}$ in water, and was shown to be identical with an authentic specimen of 2:3:4-trimethyl- $\alpha$-methyl-l-fucoside (I), kindly provided by Dr S. P. James (James \& Smith, 1944, 1945). It was further identified by hydrolysis with $0 \cdot 1 \mathrm{~N}-\mathrm{H}_{2} \mathrm{SO}_{4}$ to the free sugar, followed by

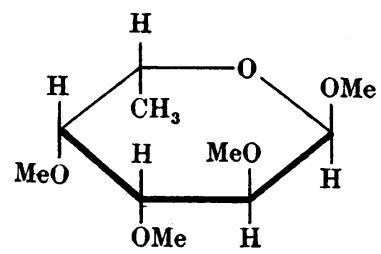

(I)

conversion to the anilide, m.p. $112-114^{\circ}$ alone or in admixture with an authentic specimen. This compound has since been isolated in an exactly similar way from a sample of an undegraded and carefully fractionated blood group A substance from hog gastric mucin which Dr W. T. J. Morgan kindly provided. It is to be noted that in both polysaccharides the $l$-fucose must be present as an end group. The yield was $c .6 \%$ of the methylated carbohydrate residue.

Identification of mannose and galactose constituents. Fraction $(b)(0.67$ g.) contained no nitrogen and was further methylated, using methyl iodide and silver oxide as before (two treatments). The resulting syrup was hydrolyzed with $2 \mathrm{~N}-\mathrm{H}_{2} \mathrm{SO}_{4}$ for $5 \mathrm{hr}$. on a boiling water-bath, the solution then being neutralized with $\mathrm{BaCO}_{3}$ and extracted with chloroform. The solvent was removed and there remained a syrup which was boiled for $\mathbf{5} \mathrm{hr}$. with absolute ethanol $(10 \mathrm{ml}$.$) containing aniline (0 \cdot 15 \mathrm{~g}$.$) . The$ ethanol and aniline were then evaporated off, leaving a brown syrup which partially crystallized. After some days at $0^{\circ}$ the crystalline material was separated and after recrystallization from ethanol-light petroleum had m.p. $143^{\circ}$, alone or in admixture with an authentic specimen of 2:3:4:6-tetramethyl mannose anilide (m.p. $142^{\circ}$ ). The mother liquors from the above crystallization on being kept deposited a second crystalline substance having m.p. $193^{\circ}$ alone or in admixture with 2:3:4:6-tetramethyl galactose anilide. Further amounts of these two anilides were separated from the mother liquors.

Identification of a glucosamine constituent. This was carried out on another typical sample of methylated stable carbohydrate residue (4 g.) from which there resulted $2 \cdot 0 \mathrm{~g}$. of ether soluble fraction $(a)$ and $2 \cdot 1 \mathrm{~g}$. of ether insoluble fractions $(b)$ and $(c)$. After removal of the fucoside fraction $(0 \cdot 20 \mathrm{~g}$.) from fraction $(a)$, the residual material was distilled in a high vacuum giving fraction $\left(a_{2}\right)$, b.p. $125^{\circ}$ at $0.15 \mathrm{~mm} ., n_{E}^{20^{\circ}}, 1.4520$ (0.41 g.); fraction $\left(a_{3}\right)$, b.p. $125-135^{\circ}$ at $0.125 \mathrm{~mm}$., $n_{D}^{20^{\circ}}, 1 \cdot 4600(0.20 \mathrm{~g}$.) ; fraction $\left(a_{4}\right)$, b.p. $140-170^{\circ}, n_{D}^{21^{\circ}}, 1 \cdot 4650(0 \cdot 31 \mathrm{~g}$.) ; and an undistilled residue $(0 \cdot 8 \mathrm{~g}$.). All these fractions gave a weak qualitative test for nitrogen but at present only fraction $\left(a_{2}\right)$ has been examined. This syrup

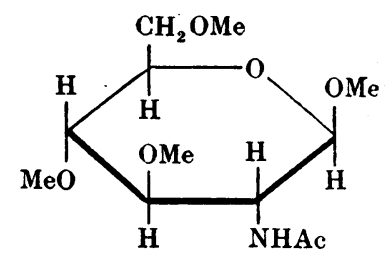

(II)

was dissolved in dry ether, dry $\mathrm{HCl}$ gas passed through and the resulting precipitate removed by centrifuging. It was recrystallized from ethanol and had m.p. $237^{\circ}$ (decomp.), alone or in admixture with an authentic specimen of 3:4:6-trimethyl $\alpha$-methyl glucosaminide hydrochloride. The identity of this 
material was confirmed by the fact that on $N$ acetylation with silver acetate and acetic anhydride in methanol it was quantitatively converted to $N$-acetyl 3:4:6-trimethyl methyl glucosaminide (II) which after recrystallization from ether-light petroleum had m.p. $148-149^{\circ}$ alone or in admixture with an authentic specimen. It would appear that part of the glucosamine constituent also is an end group (cf. Stacey \& Woolley, 1940, 1942). Other fractions, including fraction $(c)$, have not yet been examined but already it is apparent that the structure is complex and further amounts of methylated material are being collected for investigation.

\section{DISCUSSION}

In considering the foregoing experimental results as a whole the most interesting observation is that all specific substances from non-human sources display group A specificity only, so that human tissues and secretions remain the sole source of $B$ and $O$ group substances.

The inhibition of the isoagglutination reaction provides a sensitive means of detecting substances having blood group specificity (cf. Morgan, 1944) and the most active fractions can be detected in amounts of $<0 \cdot 10 \mu \mathrm{g}$. (Wiener, 1943). Since serological cross specificity depends upon a chemical structural relationship, we believe that the measure of specificity shown by some of the complex, apparently unrelated polysaccharides, will eventually be traced to a similarity in structure. Certain of the polysaccharides showed no trace of specificity and these provided useful controls; these inactive substances were for the most part devoid of detectable aminoacid residues. It was readily apparent from the examination of the most active fractions that while they were predominantly carbohydrate in nature, they contained amino-acid residues, in particular, histidine, which are apparently of high significance from the immunological point of view. This was first discovered by Landsteiner \& Harte (1940); Morgan (1944) has summarized the evidence on the matter, and, moreover, states that chromatographic methods have revealed the presence of no fewer than fifteen constituent amino-acids in the hog mucin A substance. The importance of the combination of the group A substance with poly-aminoacids was discovered by Morgan and his co-workers (1940, 1941, 1944). By mixing the A substance from gastric mucin or ovarian cysts in aqueous solution with an alkaline solution of a protein component of the O-somatic antigen of Shigella dysenteriae, there was formed at $\mathrm{pH} 4.5$ a complex which had the properties of a specific antigen. This induced in rabbits the formation of a powerful antibody which agglutinated human erythrocytes of group $A$ and which could be used to distinguish $\mathbf{A}$ sub-groups.
A study of other A substance-protein complexes will prove of great interest.

The progressive loss of activity on alkaline hydrolysis shown by the A substances from pepsin (samples $S(20), S(21)$, and $S(22)$ ) may be due to the loss of labile amino-acid residues, though further investigation of this is necessary. Our results indicate, however, that part of the structure is stable to mild alkaline treatment $\left(\mathrm{BaCO}_{3}\right.$ at $\left.70^{\circ}\right)$ since it retains a considerable degree of serological activity (e.g. showing activity at dilution of $0 \cdot 1 \mu \mathrm{g} . / \mathrm{ml}$.). Treatment with $\mathrm{N}-\mathrm{NaOH}$ decreases this activity to $10 \%$ in $30 \mathrm{~min}$. and to $1 \%$ in $4 \mathrm{hr}$. The failure to isolate from erythrocytes any substances showing group A specificity was of interest since it appeared to be correlated with the absence of amino-acid residues from the erythrocyte carbohydrates.

The effect of acetylating the factor from gastric mucin was significant for the reason that the acetate was soluble in water (cf. Stacey \& Woolley, 1940) so that its activity could be measured. Although the acetylation process would block all free hydroxyl and amino groups yet a reasonable degree of isoagglutination inhibition remained. This presumably was due to intact amino-acid constituents since deacetylation restored the former degree of activity of the complex. The polysaccharides $\mathrm{S}$ (15) from frog spawn mucin and $S(14)$ from ovomucoid resembled the other A-factors inasmuch as they completely lost their activity after saponification and removal of the detectable amino-acid constituents. It is noteworthy that both these polysaccharides possessed galactose residues and had a high content of $N$-acetyl glucosamine residues.

Only acetic acid, glucosamine and galactose have previously been detected as constituents of the A substances (Freudenberg \& Eichel, 1934; Landsteiner \& Chase, 1936; Landsteiner, 1936). The acetic acid is probably present in $N$-acetyl glucosamine and may have some effect on the specificity of the A substance (cf. Freudenberg \& Eichel, 1935).

Since direct acid hydrolysis of polysaccharides of this type tends to cause destruction of liberated monosaccharide units before the more stable parts are split (Stacey \& Woolley, 1940) it was decided to methylate the carbohydrate residue and to attempt to identify the constituent units in the form of their methyl ethers. The drastic alkaline conditions of methylation undoubtedly caused a considerable breakdown of the molecular complex since the methylated products dialyzed through parchment membranes. However, by using the conditions described, an essentially homogeneous stable methylated carbohydrate was obtained in moderate yield. From this, by acid hydrolysis using the methods described, the following substances were identified: 2:3:4:6-tetramethyl $d$-mannose; 2:3:4:6tetramethyl $d$-galactose; 3:4:6-trimethyl $N$-acetyl 
$\alpha$-methyl $d$-glucosaminide (II); 2:3:4-trimethyl $\alpha$ methyl $l$-fucoside (I). The direct isolation of the latter compound is of great interest since $l$-fucose must constitute a terminal residue, and it would appear to be the first instance of the isolation of a fucose derivative from an animal source. It has been isolated previously from sea-weed and from gum tragacanth (James \& Smith, 1944, 1945) and also in this department from a gastric mucin polysaccharide (W. O. Cutler \& S. Peat, private communication). It also appears from the direct isolation of II, that some of the $N$-acetyl glucosamine constituents are present as terminal groups. Since this investigation does not preclude the possibility that other sugar units also are present, it is evident that this stable carbohydrate residue possesses a branched chain structure of great complexity.

\section{SUMMARY}

1. Methods are described for the preparation from a wide variety of sources of polysaccharide- amino-acid complexes having blood group A specificity.

2. Alkaline hydrolysis of the A substance from pepsin causes a degradation of the molecule and a loss of the group specificity. This loss may be due at least in part to a removal of amino-acid residues.

3. Acetylated and methylated derivatives of a relatively stable carbohydrate residue from the pepsin A substance were prepared.

4. Examination of the hydrolysis products of the methylated derivative of the stable carbohydrate residue showed that $d$-galactose, $d$-mannose, $d$ glucosamine and $l$-fucose were constituent units. Part of the $d$-glucosamine and the $l$-fucose components were present as terminal groups, and the amino group of glucosamine was naturally acetylated.

The authors express their thanks to Dr H. G. Sammons and Mr M. G. Webb, who carried out preliminary experiments on some of the polysaccharide fractions.

\title{
REFERENCES
}

Fraenkel, S. \& Jellinck, C. (1927). Biochem. Z. 185, 392.

Freudenberg, K. \& Eichel, H. (1934). Liebigs Ann. 510, 240. Freudenberg, K. \& Eichel, H. (1935). Liebigs Ann. 518, 97. Goebel, F. (1938). J. exp. Med. 68, 221.

Hallauer, C. (1934). Z. ImmunForsch. 83, 114.

James, S. P. \& Smith, F. (1944). Biochem. J. 38, xxi.

James, S. P. \& Smith, F. (1945). J. chem. Soc. pp. 739, 746.

Kosjakov, P. N. (1941). Z. ImmunForsch. 99, 221.

Kosjakov, P. N. \& Tribulev, G. P. (1940). Z. ImmunForsch. 98, 261.

Landsteiner, K. (1936). J. exp. Med. 63, 185.

Landsteiner, K. \& Chase, M. W. (1936). J. exp. Med. 63, 851.

Landsteiner, K. \& Harte, R. A. (1940). J. exp. Med. 71, 551.
Morgan, W. T. J. (1944). Brit. Med. Bull. 2, 165.

Morgan, W. T. J. \& King, H. K. (1943). Biochem. J. 37, 640. Morgan, W. T. J. \& Partridge, S. M. (1940). Biochem. J. 34, 169.

Morgan, W. T. J. \& Partridge, S. M. (1941). Biochem. J. 35, 1140.

Morgan, W. T. J. \& van Heyningen, R. (1944). Brit. J. exp. Path. 25, 5.

Sevag, M. G. (1934). Biochem. Z. 273, 419.

Stacey, M. \& Woolley, J. M. (1940). J. chem. Soc. p. 184.

Stacey, M. \& Woolley, J. M. (1942). J. chem. Soc. p. 550.

Wiener, A. S. (1943). Blood Groups and Transfusion, 3rd ed. Baltimore: C. Thomas.

\section{Ghemistry of Tissues}

\section{BLOOD GROUP SUBSTANCES FROM HUMAN GASTRIC EONTENTS}

\author{
By H. G. BRAY, H. HENRY AND M. STACEY, Departments of Physiology and Chemistry, \\ University of Birmingham
}

(Received 15 September 1945)

In view of the division of the blood groups into subgroups and of the continued discovery of new factors such as the important $R h$ factor it is highly desirable to compare the chemical properties and detailed structure of the blood group specific substances from all the groups. Inasmuch as non-human sources appeared to provide only the $A$ substance, it was necessary, as an approach to the main problems, to examine secretion or tissue material from humans of the appropriate groups. It appeared that gastric contents would provide a suitable means of getting the relatively large amounts of $A, B$ and $O$ specific carbohydrates needed for chemical study. Witebsky \& Klendshoj $(1940,1941)$ have already examined, in a preliminary way, $A$ and $B$ factors prepared by Sevag's method from the gastric juice of humans in 